\title{
IMPACT OF LEAN MANUFACTURING ON THE OPERATIONAL PERFORMANCE: EVIDENCE FROM TEXTILE INDUSTRY Muhammad Naeem ${ }^{1}$, Nisar Ahmad ${ }^{*}$, Sarfraz Hussain ${ }^{3}$, Bilal Nafees ${ }^{4}$, Aatir Hamid ${ }^{5}$ \\ ${ }^{1}$ Lecturer in Commerce, Govt. M.A.O. College, Lahore, Pakistan; ${ }^{2 *}$ Assistant Professor, Hailey College of Commerce, University of the Punjab Lahore, Pakistan; ${ }^{3}$ Azman Hashim International Business School, Universiti Teknologi Malaysia, Kuala Lumpur, Malaysia, and Govt. Imamia College Sahiwal, Pakistan; ${ }^{4}$ Lecturer, Department of Economics \& Business Administration, University of Education, Lower Mall Campus Lahore, Pakistan; ${ }^{5}$ Government College University Lahore, Pakistan. \\ Email: ${ }^{1}$ naeemskpjdg@gmail.com, ${ }^{2 *}$ nisar@ 5 aatirpk@hotmail.com
}

Article History: Received on $25^{\text {th }}$ April 2021, Revised on $10^{\text {th }}$ June 2021, Published on $14^{\text {th }}$ June 2021

\begin{abstract}
Purpose of the study: Lean manufacturing is perceived to be a significant competitive advantage of firms as it removes waste from manufacturing operations with innovations in products and processes. This research aims to know the impact of lean manufacturing practices of textile firms on their operational efficiency.
\end{abstract}

Methodology: For this study, questionnaires were electronically sent to operation/ production managers of 122 textile firms using lean manufacturing technologies in Pakistan. Based on the literature review, nine lean manufacturing practices and five operational performance measures were included in the questionnaire survey. Just 91 operation managers replied, a response rate of 74\%. Multiple regression analysis was performed to test the hypotheses of the study.

Main findings: The results of regression analysis show that lean manufacturing practices significantly impact the operational performance of textile firms. The study's findings suggest that the involvement of customers, suppliers, and employees causes an increase in the operating performance of firms. Moreover, it is established that some lean manufacturing practices such as $5 \mathrm{~S}$, automation (Jidoka), Justin time (JIT), equipment layout, and continuous improvement (Kaizen) have a significant and positive effect on the operational performance of firms.

Application of the study: The lean manufacturing practices save money for businesses and increases overall productivity by reducing waste. These are also helpful in increasing consumer loyalty and employee productivity. The study's results show that lean production methods can be adopted to improve operating performance and competitiveness.

Originality/ Novelty: This study adds a piece of first-hand evidence by establishing a significant effect of lean manufacturing practices of firms on their operational performance in Pakistan, where most of the firms so far are using traditional techniques due to lack of financial resources.

Keywords: Lean Manufacturing Practices, Participatory Decision Making, Operational Performance, Textile Industry, Regression Analysis.

\section{INTRODUCTION}

Lean manufacturing (LM) strategies eliminate inefficient processes and allow businesses to become more productive. Adoption of these activities frequently contributes to a firm's longevity. Cost of production is a significant factor that needs the proper attention of manufacturing organizations. Lean manufacturing is a tool that can enhance the productivity and profitability of firms (Shurrab \& Matloub, 2018). Price, lead time, and quality control have a critical impact on the industry's overall operational efficiency. Lean practices can make the manufacturing activities in the industry quicker and less wasteful. According to Carvalho, Gonçalves, and Silva (2019), Businesses can use LM technology to gain a strategic edge in the industry. Adopting LM strategies provides businesses with a competitive advantage over their competitors (Belekoukias, Garza-Reyes \& Kumar, 2014). Enterprises delivering products through lean practices are also required to use environment-friendly techniques (Inman \& Green 2018; Moreira \& Silva-Pais, 2011). Research proved that the ultimate goal/aim of being lean and going green is to reduce waste from operations (Sarkis, 2012). As a result, LM implementation benefits both organizations and the community (Negrao., Godinho \& Marodin 2017). Lean thought puts a premium on just-in-time practices and vendor relationships (Shah \& Ward, 2003). The primary focus in lean manufacturing is on eliminating practices that do not add value to a product/service $\underline{(\text { Carvalho }}$ et al., 2019). Mazanai (2012) Cost cuts and operating performance significantly affect profitability and consumer loyalty, as previously stated. However, organizational competition has developed in recent years. According to Alsmadi, Almani, and Jerisat (2012), businesses will gain a strategic edge by adopting LM strategies. Therefore, different studies (Nogueira, Sousa, \& Moreira, 2018; Van-Landeghem, 2014, etc.) shed light on the organization's deep concerns about lean implementation. Lean eliminates inefficient processes in the chain without sacrificing the product's or service's efficiency (Vijaya, 2015). A helpful framework needed a tremendous set of standards and rules to manage the change and improvement in processes. Toyota originally introduced this in 1950 as Toyota's Production System (TPS). TPS's main objectives/goals were to reduce Muda (waste) to achieve greater productivity. Dahlgaard and Dahlgaard-Park 
(2006) highlighted the significance of the Muda concept in quality-improvement practices. TPS sets out a management system whose main aim is to reduce waste by avoiding non-value-added practices (Alsmadi et al., 2012).

Cost-cutting, pollution control, and quality improvement are lean manufacturing methods (Street, Fliedner \& Mathieson, 2009). Managers are aware of various wastes, including excess manufacturing, waiting, storage, additional refining, extra movement, and defects (Endsley, Magill, \& Godfrey, 2006). The history of lean lies in two simple terms JIT and Jidoka. Later, Gupta and Jain (2013) discussed the role of lean manufacturing in delivering high-quality products at the lowest cost. The lean philosophy stresses waste reduction by providing low-cost goods (Vinodh \& Joy, 2012). Recently, Slovic, Tomasevic, and Radovic (2016) Have known that implementing LM raises a firm's sales. In the last decade, LM has been much studied in the developed countries, whereas a small number of studies on LM are conducted in the developing world (Ghosh, 2013; Nawanir, Lim \& Othman, 2013; Ravikumar, Marimuthu \& Parthiban, 2015). The emerging world's history and economic climate are markedly different from that in industrialized countries. Therefore, the implementation of LM may be handled differently in developing countries.

In Pakistan, there has been a few exploratory studies on the LM practices of firms. Existing literature so gives an inadequate understanding of lean practices and their ultimate impact. However, in neighboring countries, some work has been done. For example, Ferdousi and Ahmed (2009) identified a strong correlation between LM activities and industrial waste reduction and cost reduction. They also observed an increase in the quality of products due to the implementation of LM practices. Recently, Bhutta, Egilmez, Chatha, and Huq (2017) The application of lean manufacturing practices was investigated in five separate manufacturing sectors in Pakistan, including the textile industry. The following table summarizes the lean production techniques used by apparel companies in Pakistan. The textile industry plays a vital role in developing countries. It improves the standards of living by providing employment opportunities. In Pakistan, this industry has contributed significantly to economic growth. It contributes $8.5 \%$ to GDP (Hashim, Baig, Amjad, Nazam, \& Akram, 2019).

Table 1: Adoption Rate of the Lean Practices

\begin{tabular}{lll}
\hline$\#$ & Practices & Textile Sector \\
\hline 1 & Set-up time reduction & $95 \%$ \\
\hline 2 & Work standardization & $98 \%$ \\
\hline 3 & Cellular manufacturing implementation & $40 \%$ \\
\hline 4 & Poke yoke implementation & $74 \%$ \\
\hline 5 & Value/Non Value added activity analysis & $58 \%$ \\
\hline 6 & Total preventive maintenance (TPM) & $93 \%$ \\
\hline 7 & Total quality management (TQM) & $77 \%$ \\
\hline 8 & 5 S implementation & $56 \%$ \\
\hline 9 & Cycle time reduction & $67 \%$ \\
\hline 10 & Automation (Jidoka) implementation & $53 \%$ \\
\hline 11 & Production scheduling improvement efforts & $100 \%$ \\
\hline 12 & Use of visual controls (Andon) & $60 \%$ \\
\hline 13 & Use of smaller lot sizes & $58 \%$ \\
\hline 14 & Implementation of Nagara System & $42 \%$ \\
\hline 15 & Use of integrated flow operations & $16 \%$ \\
\hline 16 & Pull flow control implementation & $56 \%$ \\
\hline 17 & Implementation of parts standardization & $72 \%$ \\
\hline 18 & Implementation of concurrent engineering & $51 \%$ \\
\hline 19 & Use of design for manufacturability & $47 \%$ \\
\hline 20 & Supplier evaluation & $77 \%$ \\
\hline 21 & Total cost analysis for supplier evaluation & $74 \%$ \\
\hline 22 & Exchanging information with suppliers & $88 \%$ \\
\hline 23 & Suppliers as partners & $91 \%$ \\
\hline 24 & Striving to improve delivery performance & $88 \%$ \\
\hline 25 & Strive to stabilize demand & $60 \%$ \\
\hline 26 & Strive to enhance product value & $77 \%$ \\
\hline 27 & Collecting customer requirements & $86 \%$ \\
\hline 28 & Product customization & $91 \%$ \\
\hline 29 & Implementation of worker cross-training & $67 \%$ \\
\hline & & \\
\hline
\end{tabular}

Source: Bhutta et al. (2017)

The textile industry plays a vital role in developing countries. It improves the standards of living by providing employment opportunities. In Pakistan, this industry has contributed significantly to economic growth. It contributes 8.5\% to GDP (Hashim et al., 2019). This sector's contribution is nearly one-fourth of industrial value addition and gives 
job opportunities to about forty percent $(40 \%)$ of the total labor force engaged in industrial sectors. The average share of textile products is about 59\% in national exports (Economic Survey of Pakistan 2019-20). The textile sector has a comparatively top rank with 20.91 in Quantum Index Manufacturing (QIM), and therefore its impact is more significant. Table 2 provides an industry profile of the textile sector in Pakistan.

Table 2: Industry's Profile

\begin{tabular}{cccccc}
\hline $\begin{array}{c}\text { Industry's } \\
\text { Type }\end{array}$ & $\begin{array}{c}\text { \%age of } \\
\text { GDP }\end{array}$ & $\begin{array}{c}\text { \%age of } \\
\text { Exports }\end{array}$ & $\begin{array}{c}\text { \%age of Labor } \\
\text { Force }\end{array}$ & $\begin{array}{c}\text { \%age of Foreign Direct } \\
\text { Investment FDI }\end{array}$ & $\begin{array}{c}\text { Orientation } \\
\text { Exports Vs. } \\
\text { Domestic }\end{array}$ \\
\hline $\begin{array}{c}\text { Textile } \\
\text { Industry }\end{array}$ & 8.5 & 59 & 40 & 0.67 & $\begin{array}{c}\text { Export and } \\
\text { domestic }\end{array}$ \\
\hline
\end{tabular}

Source: Economic Survey of Pakistan (2019-20)

A few earlier studies have emphasized the link between lean activities and organizational efficiency (Womack, Jones \& Roos, 2007; De Toni \& Nassimbeni, 2000; Rahman, Laosirihongthong, \& Sohal, 2010; Khanchanapong, Prajogo, Sohal, Cooper, Yeung \& Cheng, 2014). Learning from organizations that have begun to adopt new management techniques, such as lean, has a vital role in the progressive industry of Pakistan (Egilmez, Chatha, \& Huq, 2017).

Thus, the current article is devoted to examining the impact of lean practices on the operating efficiency of Pakistani textile firms.

Following an explanation of the study's inspiration, section 2 presents a critical analysis of the literature. Section 3 contains information about the data and methods used in this analysis. Section 4 finds the results of the analysis. The last, section 5, concludes the results and also highlights policy implications and future research direction.

\section{LITERATURE REVIEW}

This segment examines prior research on lean methods and corporate performance.

\section{Operational Performance}

"Operational performance (OP) relates to the manufacturing plant's capabilities to more efficiently produce and deliver products to customers" (Zhu, Sarkis, \& Lai 2008). Costs, efficiency, execution, and flexibility are the most widely used metrics for evaluating OP. Consequently, a list of indicators included the development and frequency of introducing a new product (Ahmad \& Schroeder, 2003). Nearly 50\% of the companies work closely with their customers, suppliers, and technology centers to improve their production. The supplier involvement was identified by Jasti and Kodali (2015) as the most popular lean practice. Low stock is also considered a popular lean way (Carvalho et al., 2019).

\section{Lean Practices}

As illustrated by Shah and Ward (2007), Emphasis is placed on reducing setup time, maintaining steady flow, and performing preventive maintenance, among other things. Textile producers are gradually using lean practices to improve efficiency to reduce costs and lead times (Hamja, Maalouf \& Hasle, 2019). Lean methodology is a multi-level mechanism that combines various activities in an interlinked framework, including Just-in-Time, quality processes, different work teams, development cells, and supplier management, etc. (Shah \& Ward, 2003). Processing goods and services just at the lowest cost is an objective of lean (Hopp \& Spearman, 2004). Waste management activities like reduced set-up time, small batch sizes, and a pulled system are considered part of this approach (Li, Rao, Ragu-Nathan \& Ragu-Nathan, 2005). Numerous benefits accrued to lean production firms, including improved operating productivity as a result of reduced human activity, storage time, and process overhaul (Womack et al., 2007). Recently, Hamja et al. $\underline{(2019)}$ stated that lean practices such as $5 \mathrm{~s}$, value stream diagrams, total quality control, and Kaizen had a beneficial effect on the success of businesses. . Shah and Ward (2003) presented 22 lean manufacturing practices that include supplier collaboration, kanban, continuous improvements, complete maintenance, and damage-free programs, etc. Some studies reported an increase in operational efficiency from 12.50\% to $90.00 \%$ (Carvalho et al., 2019; Marudhamuthu, Krishnaswamy \& Pillai, 2011). Marudhamuthu et al. (2011) observed a reduction of 8-28 minutes in production time per product unit. According to Wickramasinghe and Perera (2016), lean production resulted in an increase in cost-efficiency, quality of products, timely delivery of goods or services, and variability in volume. Likewise, Kaur, Marriya, and Kashyap (2016) showed improved performance due to leanness.

Lean means removing those activities that are of no value, and Kaizen means a continuous improvement. Hence the idea of Lean-Kaizen implies a constant reduction in waste by making minor adjustments in both product design and process design. Kaizen is also a common technique for disposing of waste at any company at all levels. But from the other side, Lean-Kaizen's main objective is excellence in quality, cost, and delivery (Jasti \& Kodali, 2014; Arya, \& Choudhary, 2015). The rapid acceptance of lean practices is one of the main variables for lean adoption. (Bhamu \& Sangwan, 2014). The engagement of suppliers in product or process development is vital. Consultation with the suppliers can produce goods with better design and achieve lower costs and resultantly best quality. The summary of merits achieved may be 
as: reduction in cost, better product quality, a decrease in overall development time (De Toni \& Nassimbeni, 2000). Moreira and Silva-Pais (2011) reported adopting a single-minute exchange of dies to save £362,960 per annum. Danese,

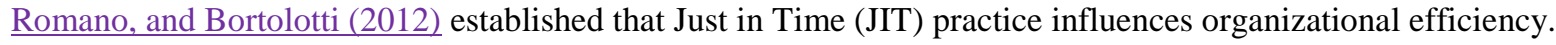

\section{Lean Organizational Efficiency and Procedures}

Khanchanapong et al. (2014) reported the value of LM practices for manufacturing operational performance. Operational performance dimensions explored in various studies are cost, quality, flexibility, and reliability. Rahman et al. (2010) found that Just-in-Time, flow management, and waste reduction are significant regarding the operational performance. Inman \& Green (2018) reported that the involvement of suppliers and customers is aimed at reducing all categories of waste from overall processes. Belekoukias, Garza-Reyes, and Kumar (2014) indicated the most significant impact of JIT on operational performance indicators: cost, reliability, quality response, speed, and flexibility. Implementing lean systems-based strategies improves organization adaptability by ensuring the product's versatility, manufacturing duration, and lead times. The performance of lean approaches eliminates waste from the manufacturing cycle, makes the movement of development more flexible, and reduces the lead-time (Bento, Schuldt \& Carvalho, 2020; Belekoukias et al., 2014). There is a positive relation, both direct and indirect, between LM Practices and Operational Performance (Inman \& Green, 2018; Negrao et al., 2017). Piercy and Rich (2015) discovered that adopting lean can lead to sustainable results. Poor adoption, therefore, will lead to better environmental performance (Negrao et al., 2017). The lean production practices have a positive effect on operational efficiency. Tourki (2010) argues that companies that embrace lean manufacturing have an advantage over others to thrive in the global economic climate. Fullerton, McWatters \& Fawson (2003) used regression analysis and stated that JIT practices could increase the business's profitability.

\section{Hypotheses development}

To examine the effect of LM practices on OP, we developed a set of hypotheses. Implementing LM removes waste from the manufacturing cycle, makes the production flow more flexible, and increases the level of response to consumer needs (Bent et al., 2020). Recently, Inman and Green (2018); Negrao et al. (2017) established a positive relationship between LM practices and OP. Some earlier studies, e.g., Abdel-Maksoud, Dugdale, and Luther (2005), Fullerton and Wempe (2009), Hallgren and Olhager (2009), Rahman et al.( 2010) also reported similar findings. The following specific hypotheses were developed for this study:

$\boldsymbol{H}_{1}$. Customer Involvement has a positive impact on OP.

$\boldsymbol{H}_{2}$. Supplier Involvement has a positive effect on OP.

$\boldsymbol{H}_{3}$. Employee Involvement has a positive effect on OP.

$\boldsymbol{H}_{4} .5 \mathrm{~S}$ has a positive impact on OP.

$\boldsymbol{H}_{5}$. Jidoka (automation) has a positive impact on OP.

$\boldsymbol{H}_{6}$. JIT (Just in Time) has a positive effect on OP.

$\boldsymbol{H}_{7}$. Equipment Layout has a positive effect on OP.

$\boldsymbol{H}_{8}$. Continuous Improvement(Kaizen) has a positive impact on OP.

$\boldsymbol{H}_{\boldsymbol{9}}$. Single Minute Exchange of Dies has a positive effect on OP.

\section{METHODOLOGY}

Some prior studies indicated that a structured questionnaire had been the most suitable method for gathering data to investigate the relationship between LM practices and operational performance (Dong, Carter, \& Dresner 2001). A structured questionnaire was submitted electronically to the operations/ production managers of textile firms working in Pakistan. There is no mutual consensus among various researchers regarding the exact number of lean manufacturing practices. Shah and Ward (2003) reported 22 lean practices, but Fullerton \& McWatters (2009) recognized only 10. Ghosh (2013) suggested seven lean ways to measure effective performance. For this study, we identified the following nine lean practices based on a comprehensive literature review.

1. Customer Involvement

2. Supplier Involvement

3. Employee Involvement

4. 5S (Sort, Set in Order, Shine, Standardize, Sustain)

5. Jidoka (automation)

6. JIT(Just-in-Time) 
7. Equipment Layout

8. Continuous Improvement(Kaizen)

9. Single Minute Exchange of Dies

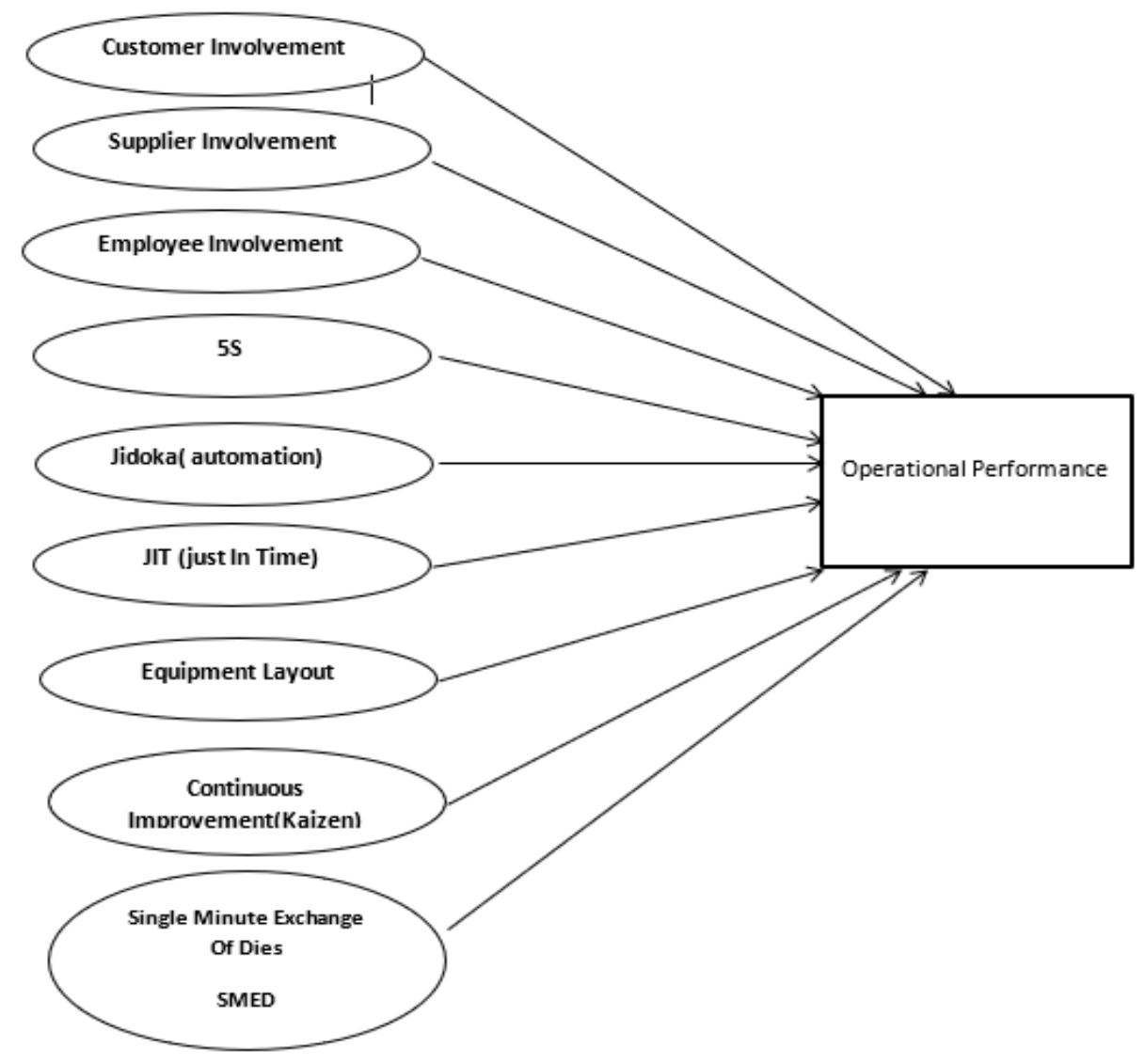

Figure 1: Conceptual Framework

Source: Author Analysis

Belekoukias, Garza-Reyes \& Kumar (2014) argued that even with incomplete adoption of lean practices, the effect on organizational efficiency and operating efficiencies are positive. This study includes six items for active performance measurement (Zhu, Sarkis, \& Lai 2008).

1. In time delivery of goods

2. Minimal inventory level

3. Reduction in waste

4. Product quality enhancement

5. Addition in the variety of products

6. Better utilization of capacity available

We used Likert scale containing five points to measure the level of lean manufacturing practices adopted by textile firms. For the measurement of lean practices;

One is for "no implementation."

Two is for "little implementation."

Three is for "some implementation."

Four is for "extensive implementation."

Five is for "complete implementation."

For the measurement of operational performance; 
One is for "not at all."

Two is for "a little bit."

Three is for "to some degree."

Four is for "relatively significant."

Five is for "significant."

There are 177 textile firms currently working in Pakistan. It includes 84 listed while 93 non-listed companies. The survey questionnaire was mailed electronically to 122 textile firms. Consistent with Yamane (1967) and (Israel (1992), we determined the sample size by using formula $\left[\mathrm{n}=\mathrm{N} / 1+\mathrm{N}(\mathrm{e})^{\wedge} 2\right]$ Here $\mathrm{n}$ denotes sample size, $\mathrm{N}$ indicates population, $\mathrm{e}$ is the level of precision, one is used for the probability of the event occurring. As a result: $=177 / 1+177(0.05)^{\wedge} 2=122$. Respondents were operations managers. It was observed at an early stage that responses are very inadequate. For increasing the number of responses, we made telephonic requests and also sent email reminders. Finally, 91 responses (response rate $=74.59 \%$ ) were actually received. Taking into consideration the response rate from previous studies, it can be concluded that, in the Pakistani context, it was a reasonable response rate. Ghosh (2013) observed a 20 percent response rate in a similar study conducted in India. Likewise, Upasani (2012) reported a similar response range of 18.02 and $17.5 \%$, respectively.

According to Park and Lord (2009), "Correlation analysis exploring relationships between variables upon another." According to Bluman (2009), "Regression is a statistical method used to describe the nature of the relationship between variables, that is, positive or negative." regression looks at the relationship that exists between dependent variables and independent variables. It shows the impact of one unit change in an independent variable on the dependent variable. Thus, for testing the hypotheses, we performed correlation and multiple regression analysis in SPSS V25.

\section{RESULTS}

For investigating the effect of LM practices on the OP of textile firms, we performed regression analysis on the data set collected through questionnaires surveys of 122 textile firms working in Pakistan. Descriptive statistics mean that standard deviation, skewness, and kurtosis are computed to describe all variables' general behavior (variation and distribution) of all variables used in the study. Descriptive statistics reported in Table 3 show that the mean value of operational performance is more than 4. It implies that, on average, the OP of textile firms has increased after implementing LM practices. Similarly, the mean statistics of LM practices is also more than 4. It implies that textile firms have adopted LM technology to a substantial extent. The standard deviation reported in Table 3 shows the variation of variables used in the study across respondents is appropriate. Therefore, the presence of outliers in the data set is less likely. To test the normal distribution of data of all variables, Kurtosis and Skewness statistics were computed, and the results are reported in Table 3. From the results, it is clear that Skewness and Kurtosis values fall within the +2 and -2 range. It implies normal distribution of data of all variables used in the study.

Table 3: Descriptive Statistics, Pearson's Correlation Coefficient Matrix and Test of Multicollinearity

\begin{tabular}{|c|c|c|c|c|c|c|c|c|c|c|c|c|c|c|}
\hline & \multicolumn{4}{|c|}{ Descriptive Statistics } & \multicolumn{10}{|c|}{ Correlation Matrix } \\
\hline & $\begin{array}{l}\text { Mea } \\
\text { n }\end{array}$ & SD & $\begin{array}{l}\text { Kurtosi } \\
\text { s }\end{array}$ & $\begin{array}{l}\text { Skewnes } \\
\text { s }\end{array}$ & CUS & SUPP & $\begin{array}{l}\text { EMPI } \\
\mathbf{N} \\
\end{array}$ & SMED & $\begin{array}{l}\text { EQLA } \\
Y \\
\end{array}$ & JITC & JITS & S5 & JID & KZN \\
\hline CUS & 4.121 & $\begin{array}{l}0.29 \\
6 \\
\end{array}$ & -0.29 & -0.29 & 1 & & & & & & & & & \\
\hline SUPP & 4.176 & $\begin{array}{l}0.32 \\
6\end{array}$ & -0.28 & -0.36 & $\begin{array}{l}0.315^{*} \\
*\end{array}$ & 1 & & & & & & & & \\
\hline EMPIN & 4.245 & $\begin{array}{l}0.37 \\
0\end{array}$ & 0.84 & -1.14 & $\begin{array}{l}0.493 * \\
*\end{array}$ & $\begin{array}{l}0.657 * \\
*\end{array}$ & 1 & & & & & & & \\
\hline SMED & 4.165 & $\begin{array}{l}0.42 \\
3\end{array}$ & 0.25 & -0.42 & $\begin{array}{l}0.441^{*} \\
*\end{array}$ & $\begin{array}{l}0.433 * \\
*\end{array}$ & $0.484 * *$ & 1 & & & & & & \\
\hline $\begin{array}{l}\text { EQLA } \\
Y\end{array}$ & 4.194 & $\begin{array}{l}0.37 \\
9 \\
\end{array}$ & 1.60 & -1.02 & $\begin{array}{l}0.418^{*} \\
*\end{array}$ & $\begin{array}{l}0.527 * \\
*\end{array}$ & $0.671 * *$ & $\begin{array}{l}0.465^{*} \\
* \\
\end{array}$ & 1 & & & & & \\
\hline JITC & 4.269 & $\begin{array}{l}0.36 \\
7\end{array}$ & -0.37 & -0.17 & $\begin{array}{l}0.307^{*} \\
*\end{array}$ & $\begin{array}{l}0.352 * \\
*\end{array}$ & $0.431 * *$ & $\begin{array}{l}0.488^{*} \\
*\end{array}$ & $0.376^{* *}$ & 1 & & & & \\
\hline JITS & 4.245 & $\begin{array}{l}0.39 \\
4\end{array}$ & -0.90 & -0.25 & $\begin{array}{l}0.307^{*} \\
* \\
\end{array}$ & $\begin{array}{l}0.352^{*} \\
* \\
\end{array}$ & $0.431 * *$ & $\begin{array}{l}0.488^{*} \\
* \\
\end{array}$ & $0.376^{* *}$ & $\begin{array}{l}1.00 *^{*} \\
* \\
\end{array}$ & 1 & & & \\
\hline S5 & 4.253 & $\begin{array}{l}0.44 \\
0 \\
\end{array}$ & 0.32 & -0.35 & $\begin{array}{l}0.541^{*} \\
* \\
\end{array}$ & $\begin{array}{l}0.480 * \\
* \\
\end{array}$ & $0.600 * *$ & $\begin{array}{l}0.485 * \\
* \\
\end{array}$ & $0.503 * *$ & $\begin{array}{l}0.602 * \\
* \\
\end{array}$ & $\begin{array}{l}0.602 * \\
* \\
\end{array}$ & 1 & & \\
\hline JID & 4.225 & $\begin{array}{l}0.36 \\
0 \\
\end{array}$ & 0.47 & -0.67 & $\begin{array}{l}0.394 * \\
* \\
\end{array}$ & $\begin{array}{l}0.644 * \\
* \\
\end{array}$ & $0.508 * *$ & $\begin{array}{l}0.691 * \\
* \\
\end{array}$ & $0.316 * *$ & $\begin{array}{l}0.328 * \\
* \\
\end{array}$ & $\begin{array}{l}0.328^{*} \\
* \\
\end{array}$ & $\begin{array}{l}0.518 * \\
* \\
\end{array}$ & 1 & \\
\hline KZN & 4.211 & $\begin{array}{l}0.30 \\
9\end{array}$ & -0.44 & -0.59 & $\begin{array}{l}0.290 * \\
*\end{array}$ & $\begin{array}{l}0.481 * \\
*\end{array}$ & $0.536 * *$ & $\begin{array}{l}0.455^{*} \\
*\end{array}$ & $0.498 * *$ & $\begin{array}{l}0.581 * \\
*\end{array}$ & $\begin{array}{l}0.581^{*} \\
*\end{array}$ & $.615^{* *}$ & $\begin{array}{l}0.543 * \\
*\end{array}$ & 1 \\
\hline OP & 4.176 & $\begin{array}{l}0.38 \\
0\end{array}$ & -0.66 & -0.11 & $\begin{array}{l}0.454 * \\
*\end{array}$ & $\begin{array}{l}0.316^{*} \\
*\end{array}$ & $0.406 * *$ & $\begin{array}{l}0.366^{*} \\
*\end{array}$ & $0.234 * *$ & $\begin{array}{l}0.208 * \\
*\end{array}$ & $\begin{array}{l}0.208^{*} \\
*\end{array}$ & $.272 * *$ & $.305^{* *}$ & $\begin{array}{l}.227 * \\
*\end{array}$ \\
\hline \multicolumn{3}{|c|}{ Test for Multicollinearity } & $\begin{array}{l}\text { Tolerance } \\
\text { VIF }\end{array}$ & & $\begin{array}{l}0.604 \\
1.656\end{array}$ & $\begin{array}{l}0.388 \\
2.579\end{array}$ & $\begin{array}{l}0.361 \\
2.772\end{array}$ & $\begin{array}{l}0.366 \\
2.733\end{array}$ & $\begin{array}{l}0.422 \\
2.371\end{array}$ & $\begin{array}{l}0.352 \\
2.034\end{array}$ & $\begin{array}{l}0.481 \\
2.077\end{array}$ & $\begin{array}{l}0.385 \\
2.596\end{array}$ & $\begin{array}{l}0.274 \\
3.651\end{array}$ & $\begin{array}{l}0.429 \\
2.334\end{array}$ \\
\hline
\end{tabular}

Notes: **. Correlation is significant at the 0.01 level *. Correlation is significant at the 0.05 level. CUS. are customers; SUPP. Are suppliers; EMPIN is employees' involvement; SMED; is a single minute exchange of dies; EQLAY is 
equipment layout; JITC is just in time linked with customers; JITS is just in time linked with suppliers, S5, is 5s; JID, is jidoka (automation); KZN is Kaizen (continuous improvement), and OP, is operational performance.

Multicollinearity means that two or sometimes more than two independent variables in multiple regression are very much correlated and can give rise to a collinearity issue (Martz, 2013). Further, to check the degree of association among the variables, the Pearson Correlation test was performed, and its results are reported in Table 3. Coefficients of all independent variables (lean management practices) with OP are positive and significant at 0.01 level. It implies that firms that have implemented LM practices to a more substantial extent demonstrate superior operational performance. Further, the coefficients of correlation between independent variables are smaller than 0.70 , which shows a weak association among the lean manufacturing practices. Moreover, similar to Ahmad and Afza (2018), we performed a VIF test to confirm the absence of severity of multicollinearity problem. From Tolerance and VIF's values in Table 3, it is clear that tolerance values are above 0.10, and similarly, all VIF values are less than 5. Therefore, the problem of the severity of multicollinearity among the lean manufacturing practices does not exist because all the variables fulfill the criteria of tolerance (should be $>0.1$ ) or VIF (variance inflation factor), which is $<3$. Therefore, all independent variables can be jointly regressed in a single regression model.

Table 4: Model Summary

\begin{tabular}{ccccc}
\hline Model & R & R-Square & Adjusted R-Square & Std. Error of the Estimate \\
\hline 1 & 0.803 & 0.647 & 0.636 & 0.28555 \\
\hline
\end{tabular}

From the values given in Table 4, the value of R-square is decisive. R-square (coefficient of determination) offers the degree of influence of LM practices (independent variables) over operational performance (dependent variables). This value shows a $64.7 \%$ influence of lean practices taken for this study, and the remaining $35 \%$ is due to other factors described by an error term. It shows that specific lean practices taken for analysis have a high degree of influence for better operational performance. R-Square's value from $60 \%$ to $69 \%$ range means that model is a good fit.

Table 5: Analysis of Variance

\begin{tabular}{lccccc}
\hline Model & Sum of Squares & Df & Mean Square & F & Sig. \\
\hline Regression & 15.338 & 5 & 3.812 & 47.073 & 0.000 \\
\hline Residual & 8.331 & 101 & 0.081 & & \\
\hline Total & 23.669 & 106 & & & \\
\hline
\end{tabular}

From the ANOVA Table 5, a $p$-value of 0.000 , which is less than 0.05 , demonstrates that the operational performance model is significant at the $1 \%$ significance. The $F$-statistic was 47.073 with a $P$-value $=0.000$ which is $<0.05$. It shows that LM practices examined for this study have a statistically significant effect on the OP of textile firms.

Table 6 demonstrates the impact of each lean practice adopted by firms on their OP. It can be seen that customers involvement practices are positively related to OP at a $5 \%$ level of significance $(\beta=0.330 ; p=0.003<0.05)$. Suppliers involvement practices have a positive effect on OP at a $5 \%$ level of significance $(\beta=0.431 ; p=0.000<0.05)$. Employees' involvement and OP are positively related at a $5 \%$ level of significance $(\beta=0.275 ; p=0.003<0.05)$. Single minute exchange of dies relationship with OP is not significant at a $5 \%$ level of significance $(\beta=0.199 ; p=0.367>0.05)$. Equipment layout practices are positively related to OP at a $5 \%$ level of significance $(\beta=0.268 ; p=0.008<0.05)$. Just-inTime (inked with customers), has a positive relationship with OP at a $5 \%$ level of significance $(\beta=0.266 ; p=0.003<$ 0.05). Just-in -Time (linked with supplier practices), has a positive and significant impact on OP at a $5 \%$ level of significance $(\beta=0.213 ; p=0.004<0.05)$. 5S practices have a positive impact on OP at a $5 \%$ level of significance $(\beta=0.101 ; p=0.004<0.05)$. Jidoka practices are positively related to $\mathrm{OP}$ at a $5 \%$ level of significance $(\beta=0.369 ; p=0.003$ $<0.05)$. The results show positive relationship between Kaizen practices and OP, which is significant at a $5 \%(\beta=0.256$; $p=0.005<0.05$ ).

Following is the demonstration of the regression model after adding values of Betas.

\section{$\mathrm{Y}=2.182+0.330$ (Cus)+0.431(SUPP)+0.275(EMPIN)+0.199(SMED)+0.268(EQLAY)+0.266(JITC)+0.213(JITS)+0.101( S5) $+0.369(\mathrm{JID})+0.256(\mathrm{KZN})$}

All the coefficients have a positive sign, which means that an increase in the adoption of LM practices causes an increase in the operational performance of firms. The coefficients for all selected lean practices indicate that LM practices are adopted at a large scale and have contributed significantly to the best operational performance of firms. The consistency of regression coefficients of selected lean manufacturing practices suggests that these variables are the critical factors that influence the operational efficiency to a varying degree.

Table 6: Significance and Distribution of Coefficients

\begin{tabular}{ccccccc}
\hline & \multicolumn{2}{c}{ Unstandardized Coefficients } & Standardized Coefficients & & \\
\cline { 1 - 4 } Model & B & Std. Error & Beta & T & Sig. \\
\hline (Constant) & 2.182 & 0.489 & & 4.467 & 0.000 \\
\hline
\end{tabular}




\begin{tabular}{clllll}
\hline CU & 0.330 & 0.109 & 0.364 & 3.036 & 0.003 \\
\hline SUPP & 0.431 & 0.090 & 0.405 & 4.773 & 0.000 \\
\hline EMPIN & 0.275 & 0.089 & 0.274 & 3.073 & 0.003 \\
\hline SMED & 0.199 & 0.120 & 0.254 & 0.102 & 0.367 \\
\hline EQLAY & 0.268 & 0.095 & 0.306 & 2.389 & 0.008 \\
\hline JITC & 0.266 & 0.127 & 0.308 & 2.047 & 0.003 \\
\hline JITS & 0.213 & 0.090 & 0.278 & 2.047 & 0.004 \\
\hline S5 & 0.101 & 0.124 & 0.365 & 3.705 & 0.004 \\
\hline JID & 0.369 & 0.171 & 0.341 & 3.200 & 0.003 \\
\hline KZN & 0.256 & 0.119 & 0.472 & 2.436 & 0.005 \\
\hline
\end{tabular}

Note: CUS is customers; SUPP is suppliers; EMPIN is employee involvement; SMED is a single minute exchange of dies; EQLAY is equipment layout; JITC is just in time linked with customers; JITS is just in time connected with suppliers; $\mathrm{S} 5$ is $5 \mathrm{~s}$, JID, is jidoka (automation); KZN, is Kaizen (continuous improvement); and OP is operational performance.

\section{DISCUSSION}

The results reported in the preceding section show that companies will cut wasteful processes and increase their efficiency by implementing lean procedures. The lean strategies save money for businesses and increase overall productivity by reducing waste and enlightening consumer loyalty. It is consistent with the findings of an earlier study conducted by Bento, Schuldt, and Carvalho in 2020. Similar to the results of Inman and Green (2018), significant and positive coefficients for the involvement of customers, employees, and suppliers, show that management of firms can increase the operational performance of their firms by sharing their production plans and quality standards with their suppliers, customers and employees. The involvement of suppliers as well as customers helps to reduce all categories of waste from the operations. The coefficient of JIT is positive and significant, which establishes that management can save various inventory-related costs by implementing the JIT system in their organizations. Some earlier studies also reported similar results, e.g., Bento et al. (2020), Belekoukias et al. (2014), Rahman et al. (2010). They emphasized the use of the JIT system for the reduction of various wastes from operations. The results establish that JIT improves the operational performance, e.g., reduction in production cost and response time, improvement of reliability and quality, increased speed, and flexibility of operations. A positive and significant coefficient of Continuous Improvement (Kaizen) shows that management can improve operational performance by introducing marginal changes in the operations continuously. Some prior studies, e.g., Hamja et al. (2019), Vamsi et al. (2014), Arya and Choudhary (2015), also established a positive impact of Kaizen on operational performance. Furthermore, we found that 5S (Sort, Set in Order, Shine, Standardize, Sustain) and Jidoka (automation) also have a positive and significant effect on the performance of firms.

\section{CONCLUSION}

The findings of the current study conclude that lean manufacturing practices have a significant impact on the operational performance of firms. For improving the operating performance of firms, their top management should give due consideration to the adoption of lean manufacturing practices in strategic planning. It also lets the firms concentrate on optimizing products and services based on consumer trust \& desire. This study emphasizes that along with implementing LM, comprehensive preparation and full support from the workforce are essential for enhancing operational efficiency. Moreover, LM practices focused on by this study should be adopted by firms for increasing OP. The continuous change supports the lean process by creating a community where every employee, from the CEO to the manufacturing assistant, looks for alternatives to increase the business growth. Specific and relatively small modifications over time yield substantial effects. It is important to share how the company has made improvements. It will show the effectiveness of the programs and will allow employees to come forward with new ideas. Organizations may also promote the participation of employees by encouraging them to implement their ideas. It shows workers should be relied on for making Kaizen a vital part of the company's culture (Ghosh 2013). The use of 5S in businesses can facilitate fast development and quality improvement in all operations.

Furthermore, the removal of unnecessary items or activities brings comfort and efficiency. Workers should make their clean workplace daily to recognize potential issues and create a motivational environment. The findings of this study suggest the policymakers emphasize the implementation of LM practices in small and medium-sized businesses in the developing market.

\section{FUTURE RESEARCH DIRECTIONS}

For generalizing the findings of this study, we suggest more investigation in other manufacturing and service industries facing very complex and varying backgrounds. Moreover, the effect of lean adoption is not limited to organizational effectiveness alone; it also enhances financial, social, and environmental performance. Thus, researchers doing additional studies on LM activities could stress the effect of lean manufacturing processes on the competitiveness of businesses. 


\section{AUTHORS CONTRIBUTION}

Muhammad Naeem (Principal Author) conceived the idea of this paper and worked on the introduction, methodology, and discussion section. He also developed the motivation for this study by rationalizing the research gap. Further, he also extended his guidance to coauthors in performing data analysis. He also worked to address the changes suggested by the editor and independent reviewers.

Nisar Ahmad (Corresponding Author) worked on the significance of the study, literature review, discussion, conclusion, and reference section. He analyzed the data. He also reviewed the whole paper and made significant improvements in the abstract, discussion, recommendation, and reference section. As a corresponding author, he made his best efforts in submitting a timely reply to the editor after incorporating the changes suggested by independent reviewers and the editor.

Sarfraz Hussain, Bilal Nafees, and Aatir Hamid worked on data collection, preparation of data file, critical review of literature, analysis, and reporting of the results. They also worked on the discussion and reference section. Their efforts are commendable in the preparation of the initial draft.

Thus, all authors have made a significant contribution to this manuscript.

\section{REFERENCES}

1. Abdel-Maksoud, A., Dugdale, D., \& Luther, R. (2005). Non-financial performance measurement in manufacturing companies. The British Accounting Review, 37(3), 261-297. https://doi.org/10.1016/j. bar.2005.03.003

2. Ahmad, N., \& Afza, T. (2018). Determinants of trade credit financing: Case of manufacturing firms listed in Pakistan. Pakistan Business Review, 20(1), 110-121. DOI: http://dx.doi.org/10.22555/pbr.v20i1.1295

3. Ahmad, S., \& Schroeder, R. G. (2003). The impact of human resource management practices on operational performance: recognizing country and industry differences. Journal of Operations Management, 21(1), 19-43. https://doi.org/10.1016/S0272-6963(02)00056-6

4. Alsmadi, M., Almani, A., \& Jerisat, R. (2012). A comparative analysis of lean practices and performance in the UK manufacturing and service sector firms. Total Quality Management \& Business Excellence, 23(3-4), 381396. https://doi.org/10.1080/14783363.2012.669993.

5. Arya, A. K., \& Choudhary, S. (2015). Assessing the Application of Kaizen principles in Indian small-scale industry. International Journal of Lean Six Sigma. 6(4). 369-396. DOI:10.1108/IJLSS-11-2014-0033.

6. Belekoukias, I., Garza-Reyes, J. A., \& Kumar, V. (2014). The impact of lean methods and tools on the operational performance of manufacturing organizations. International Journal of Production Research, 52(18), 5346-5366. https://doi.org/10.1080/00207543.2014.903348

7. Bento, G. D. S., Schuldt, K. S., \& Carvalho, L. C. D. (2020). The influence of supplier integration and lean practices adoption on operational performance. Gestão \& Produção, 27(1), 1-15. https://doi.org/10.1590/0104$\underline{530 \times 3339-20}$

8. Bhamu, J., \& Sangwan, K. (2014). Lean manufacturing: Literature review and research issues. International Journal of Operations \& Production Management, 34, 876-940. https://doi.org/10.1108/IJOPM-08-2012-0315

9. Bhutta, M. K. S., Egilmez, G., Chatha, K.A., \& Huq, F. (2017). Survey of lean management practices in Pakistani industrial sectors. International Journal of Services and Operations Management, 28(3), 309-334. http://doi.org/10.1504/IJSOM.2017.087287

10. Bluman, A. G. (2009). Elementary statistics: A step-by-step approach. New York, NY: McGraw-Hill Higher Education.

11. Carvalho, C. P., Gonçalves, L. W. N., \& Silva, M. B. (2019). Future stream mapping. International Journal of Production Management and Engineering,7(1), 1-62. https://doi.org/10.4995/ijpme.2019.8607

12. Carvalho, C.P., Gonçalves, L.W.N. and Silva, M.B. (2019). Value stream mapping as a lean manufacturing tool: A new account approach for cost saving in a textile company. International Journal of Production Management and Engineering, 6(2), 1-12. https://doi.org/10.4995/ijpme.2019.8607

13. Danese, P., Romano, P. and Bortolotti, T. (2012). JIT production, JIT supply and performance: Investigating the moderating effects. Industrial Management \& Data Systems, 112(3), 441-465. https://doi.org/10.1108/0263 $\underline{5571211210068}$

14. Dong, Y., Carter, C. R., \& Dresner, M. E. (2001). JIT purchasing and performance: an exploratory analysis of buyer and supplier perspectives. Journal of Operations Management, 19(4), 471-483. https://doi.org/10.10 16/S0272-6963(00)00066-8

15. De Toni, A., \& Nassimbeni, G. (2000). Just-in-time purchasing: an empirical study of operational practices, supplier development and performance. Omega, 28(6), 631-651. https://doi.org/10.1016/S0305-0483(00)00016$\underline{5}$

16. Economic Adviser's Wing, Finance Division, Government of Pakistan, Islamabad (2020). Pakistan Economic Survey 2019-20. http://www.finance.gov.pk/survey/chapter_20/PES_2019_20.pdf

17. Endsley, S., Magill, M. K., \& Godfrey, M. (2006). Creating a lean practice. Family Practice Management, 
13(4), 34-38.

18. Fullerton, R. R., \& Wempe, W. F. (2009). Lean manufacturing, non-financial performance measures, and financial performance. International Journal of Operations \& Production Management, 29(3), 214-240.

19. Fullerton, R. R., McWatters, C. S., \& Fawson, C. (2003). An examination of the relationships between JIT and financial performance. Journal of Operations Management, 21(4), 383-404. https://doi.org/10.1016/S02726963(03)00002-0

20. Ghosh, M. (2013). Lean manufacturing performance in Indian manufacturing plants. Journal of Manufacturing Technology Management, 24(1), 113-122. https://doi.org/10.1108/17410381311287517

21. Gupta, S., \& Jain, S. K. (2013). A literature review of lean manufacturing. International Journal of Management Science and Engineering Management, 8(4), 241-249.

22. Hallgren, M., \& Olhager, J. (2009). Lean and agile manufacturing: external and internal drivers and performance outcomes. International Journal of Operations \& Production Management, 29(10), 976-999. https://doi.org/10.1108/01443570910993456

23. Hamja, A., Maalouf, M., \& Hasle, P. (2019). The effect of lean on occupational health and safety and productivity in the garment industry - a literature review. Production \& Manufacturing Research, 7(1), 316334.

24. Hashim M., Baig S.A., Amjad F., Nazam M., Akram M.U. (2019, August). Impact of supply chain management practices on organizational performance and the moderating role of innovation culture: A case of Pakistan textile industry. In International Conference on Management Science and Engineering Management (pp. 390401). Springer, Cham.

25. Hopp, W. J., \& Spearman, M. L. (2004). To pull or not to pull: What is the question?. Manufacturing \& Service Operations Management, 6(2), 133-148. https://doi.org/10.1287/msom.1030.0028

26. Inman, R. A., \& Green, K. W. (2018). Lean and green combine to impact environmental and operational performance. International Journal of Production Research, 56(14), 4802-4818,

27. Israel, G. D. (1992). Determining sample size (Fact sheet PEOD-6). Gainesville, FL: University of Florida.

28. Jasti, N. V. K., \& Kodali, R. (2014). Lean production: Literature review and trends. International Journal of Production Research, 53(3), 867-885.

29. Jasti, N. V. K., \& Kodali, R. (2015). A critical review of lean supply chain management frameworks: a proposed framework. Production Planning \& Control, 26(13), 1051-1068. https://doi.org/10.1080/09537 287.2015.1004563

30. Kaur, P., Marriya, K., \& Kashyap, R. (2016). Assessment of lean initiatives: An investigation in the Indian Apparel Export Industry. Prabandhan: Indian Journal of Management, 9(9), 52-66.

31. Khanchanapong, T., Prajogo, D., Sohal, A. S., Cooper, B. K., Yeung, A. C., \& Cheng, T. C. E. (2014). The unique and complementary effects of manufacturing technologies and lean practices on manufacturing operational performance. Int. J. Production Economics, 153, 191-203. https://doi.org/10.1016/j .ijpe.2014.02.021

32. Van-Landeghem, H. (2014). A management system for sustainable lean implementation. In Handbook of research on design and management of lean production systems (pp. 173-187). IGI Global.

33. Li, S., Rao, S. S, Ragu-Nathan, T.S., \& Ragu-Nathan, B. (2005). Development and validation of a measurement instrument for studying supply chain management practices. Journal of Operations Management, 23(6), 618641. https://doi.org/10.1016/j.jom.2005.01.002

34. Martz, W. (2013). Evaluating organizational performance rational, natural, and open system models. American Journal of Evaluation 34(3). 385-401.

35. Marudhamuthu, R., Krishnaswamy, M., \& Pillai, D. M. (2011). The development and implementation of lean manufacturing techniques in the Indian garment industry. Jordan Journal of Mechanical \& Industrial Engineering, (5)6, 527-532.

36. Moreira, A. C., \& Silva Pais, G. C. (2011). Single minute exchange of die. A case study implementation. Journal of Technology Management \&Amp; Innovation, 6(1), 129-146. https://doi.org/10.4067/S071827242011000100011

37. Nawanir, G., Lim, K. T., \& Othman, S.N. (2013). Impact of lean practices on operations performance and business performance: Some evidence from Indonesian manufacturing companies. Journal of Manufacturing Technology Management, 24(7), 1019-1050.

38. Negrao, L. L. L., Godinho Filho, M., \& Marodin, G. (2017). Lean practices and their effect on performance: a literature review. Production Planning \& Control, 28(1),33-56.

39. Nogueira, D.M.d.C., Sousa, P.S.A., \& Moreira, M.R.A. (2018). The relationship between leadership style and the success of Lean management implementation. Leadership \& Organization Development Journal, 39(6), 807-824. https://doi.org/10.1108/LODJ-05-2018-0192

40. Park, B. J., \& Lord, D. (2009). application of finite mixture models for vehicle crash data analysis. Accident Analysis \& Prevention, 41(4), 683-691. http://doi.org/10.1016/j.aap.2009.03.007

41. Piercy, N., \& Rich, N. (2015). The relationship between lean operations and sustainable operations. International Journal of Operations \& Production Management, 35(2), 282-315. https://doi.org 
/10.1108/IJOPM-03-2014-0143

42. Rahman, S., Laosirihongthong, T., \& Sohal, A. (2010). Impact of lean strategy on operational performance: A study of Thai manufacturing companies. Journal of Manufacturing Technology Management, 21(7), 839 - 852. https://doi.org/10.1108/17410381011077946

43. Ravikumar, M.M., Marimuthu, K., \& Parthiban, P. (2015). Evaluating lean implementation performance in Indian MSMEs using ISM and AHP models. International Journal of Services and Operations Management, 22(1), 21-39.

44. Shah, R., \& Ward, P. T. (2003). Lean manufacturing: context, practice bundles, and performance. Journal of Operations Management, 21(2), 129-149. https://doi.org/10.1016/S0272-6963(02)00108-0

45. Shah, R., \& Ward, P. T. (2007). Defining and developing measures of lean production. Journal of Operations Management, 25(4), 785-805. https://doi.org/10.1016/j.jom.2007.01.019

46. Shurrab, J. \& Hussain, M. (2018). An empirical study of the impact of lean on the performance of the construction industry in UAE. Journal of Engineering, Design and Technology,16(5), 694-710. https://doi.org/10.1108/JEDT-09-2017-0095

47. Slovic, D., Tomašević, I., \& Radović, M. (2016). Improving productivity in the apparel industry through gain sharing and continuous process improvement: The case of a Serbian manufacturer. Fibres \& Textiles in Eastern Europe, 24(2), 15-22.

48. Tourki, T. (2010). Implementation of lean within the cement industry, De Montfort University (Doctoral dissertation). http://hdl.handle.net/2086/4577

49. Upasani, S. (2012). Emerging supply chain management practices in Indian manufacturing industries. International Journal of Research in IT \& Management, 2(2), 1237-1248.

50. Vijaya S., M. (2015). Corporate perspectives: commonalities and differences between Six Sigma and Lean. Sigma, 6(3), 281-288. https://doi.org/10.1108/IJLSS-12-2014-0038

51. Vinodh, S., \& Joy, D. (2012). Structural equation modelling of sustainable manufacturing practices. Clean Technologies and Environmental Policy, 14(1), 79-84.

52. Wickramasinghe, G. \& Perera, A. (2016). Effect of total productive maintenance practices on manufacturing performance: Investigation of textile and apparel manufacturing firms. Journal of Manufacturing Technology Management, 27(5), 713-729. https://doi.org/10.1108/JMTM-09-2015-0074

53. Womack, J., Jones, D. \& Roos, D. (2007). The machine that changed the world: The story of lean production, Toyota's secret weapon in the global car wars that is now revolutionizing. World Industry. New York: Free Press.

54. Zhu, Q., Sarkis, J., \& Lai, K. H. (2008). Green supply chain management implications for "closing the loop". Transportation Research Part E: Logistics and Transportation Review, 44(1), 1-18. 